\title{
Al $_{30}$ ПИЛЛАРНЫЙ МОНТМОРИЛЛОНИТ С УЛУЧШЕННЫМИ ТЕКСТУРНЫМИ СВОЙСТВАМИ ОБУСЛОВЛЕННЫМИ ПРЕДВАРИТЕЛЬНОЙ МЕХАНИЧЕСКОЙ ОБРАБОТКОЙ
}

\author{
М.Ф. Бутман, Н.С. Карасев, Н.Л. Овчинников, А.В. Виноградов
}

Михаил Федорович Бутман *, Никита Сергеевич Карасев, Николай Львович Овчинников

Кафедра технологии керамики и наноматериалов, Ивановский государственный химико-технологический университет, пр. Шереметевский, 7, Иваново, Российская Федерация, 153000

E-mail: butman@isuct.ru*,kns92@lenta.ru, ovchinnikovnl_1972@mail.ru

Александр Валентинович Виноградов

Кафедра химии и молекулярной биологии, Санкт-Петербургский национальный исследовательский университет информационных технологий, механики и оптики, пр. Кронверкский, 49, Санкт-Петербург, Российская Федерация, 197101

E-mail:avv@scamt-itmo.ru

Изучено влияние механической обработки природного монтмориллонита в планетарно-центробежной мельнице на эффективность интеркаляции полигидроксокомплексов алюминия $\left[\mathrm{Al}_{30} \mathrm{O}_{8}(\mathrm{OH})_{56}\left(\mathrm{H}_{2} \mathrm{O}\right)_{26}\right]^{18+}$ при формировании пилларных структур. Измерения методом фотометрии показали, что в монтмориллонитовой матрице после интеркаляции полигидроксокомплексов $\mathrm{Al}_{30}$ с использованием механической обработки наблюдалось увеличение содерэжания ионов $\mathrm{Al}^{3+}$ на 13\%. По данным электрофоретического рассеяния света, размер частиц суспензии диспергированного в воде механоактивированного монтмориллонита составил около 100 нм. Исходный, механоактивированный и пилларный монтмориллонит охарактеризованы методами малоугловой дифракции рентгеновских лучей, сканирующей электронной микроскопии и низкотемпературной адсорбции-десорбции азота. Показано, что предварительная механоактивация исходного субстрата увеличивает базальное расстояние $d_{001}$ и существенно (примерно на 45-50\%) повыщает удельную площадь поверхности

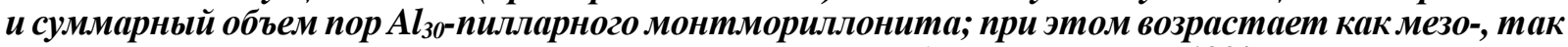
и микропористость, а размеры пор уменьшаются приблизительно на 12\%. Установлена особая важжность размеров частиц монтмориллонита при интеркаляции и дальнейщем формировании пилларной структуры. Уменьшение размера частиц монтмориллонита при механической обработке увеличивает площадь межффазной границы, через которую происходит ионный обмен. Показано, что малые размеры тактоидов (около 100 нм) в водной суспензии играют ключевую роль в увеличении катионообменной способности механоактивированного монтмориллонита. В меньщей степени на эффективность интеркаляции влияют процессы дефектообразования и связанные с этим изменения электрических свойств силикатных слоев монтмориллонита. Исходя из особенностей структурных свойств, полученные пилларные материалы могут быть рекомендованы для использования в качестве селективных адсорбентов, молекулярных сит и катализаторов.

Ключевые слова: пилларный монтмориллонит, механическая активация, полигидроксокомплексы алюминия, ионы Кеггина, интеркаляция

\section{Al 30 -PILLARED MONTMORILLONITE WITH ENHANCED TEXTURAL PROPERTIES DUE TO PRELIMINARY MECHANICAL TREATMENT}

\author{
M.F. Butman, N.S. Karasev, N.L. Ovchinnikov, A.V. Vinogradov
}

Mikhail F. Butman *, Nikita S. Karasev, Nikolay L. Ovchinnikov

Department of Technology of Ceramics and Nanomaterials, Ivanovo State University of Chemistry and Technology, Sheremetevsky ave., 7, Ivanovo, 153000, Russia

E-mail: butman@isuct.ru*, kns92@lenta.ru, ovchinnikovnl_1972@mail.ru

Alexander V. Vinogradov

Department of Chemistry and Molecular Biology, Saint Petersburg National Research University of Information Technologies, Mechanics and Optics, Kronverksky ave., 49, St. Petersburg, 197101, Russia

E-mail:avv@scamt-itmo.ru 
The effect of mechanical treatment of natural montmorillonite in a planetary-centrifugal mill on the efficiency of intercalating aluminum polyhydroxocomplexes $\left[\mathrm{Al}_{30} \mathrm{O} \mathrm{O}_{8}(\mathrm{OH})_{56}\left(\mathrm{H}_{2} \mathrm{O}\right)_{26}\right]^{18+}$ in the formation of pillared structures was studied. Measurements made using the photometry method showed that in the montmorillonite matrix, after intercalation of the $\mathrm{Al}_{30}$ polyhydroxocomplexes using mechanical treatment, an increase in the content of $A l^{3+}$ cations by $13 \%$ was observed. According to the electrophoretic light scattering data, the particle size for the suspension of mechanically activated montmorillonite dispersed in water was about $100 \mathrm{~nm}$. The raw, mechanically activated and pillared montmorillonites are characterized by the methods of low-angle X-ray diffraction, scanning electron microscopy, and low-temperature nitrogen adsorption-desorption. It was shown that preliminary mechanical activation of the initial substrate increases the basal distance $d_{001}$ and significantly (approximately by 45-50\%) increases the specific surface area and the total pore volume of $A l_{30}$-pillared montmorillonite; in this case, both meso- and microporosity increase, and the pore size decreases by about $12 \%$. The special importance of the size of montmorillonite particles during the intercalation and further formation of the pillared structure is shown. $A$ decrease in the size of the montmorillonite particles during mechanical treatment increasing the area of the interphase boundary through which ion exchange takes place. It was shown that the small sizes of tactoids (about $100 \mathrm{~nm}$ ) in an aqueous suspension play a key role in increasing the cation exchange capacity of mechanically activated montmorillonite. To a lesser extent, the efficiency of intercalation is influenced by the processes of defect formation and the related changes in the electrical properties of the silicate layers of montmorillonite. Based on the structural properties, the obtained pillared materials can be recommended for use as selective adsorbents, molecular sieves and catalysts.

Key words: pillared montmorillonite, mechanical activation, aluminum polyhydroxocomplexes, Keggin-type ions, intercalation

Для цитирования:

Бутман М.Ф., Карасев Н.С., Овчинников Н.Л., Виноградов А.В. Аl 30 -пилларный монтмориллонит с улучшенными текстурными свойствами обусловленными предварительной механической обработкой. Изв. вузов. Химия и хим. технология. 2019. Т. 62. Вып. 12. С. 45-50

For citation:

Butman M.F., Karasev N.S., Ovchinnikov N.L., Vinogradov A.V. Al 30 -pillared montmorillonite with enhanced textural properties due to preliminary mechanical treatment. Izv. Vyssh. Uchebn. Zaved. Khim. Khim. Tekhnol. 2019. V. 62. N 12. P. 45-50

\section{INTRODUCTION}

Recently, methods for obtaining new environmentally friendly polyfunctional nanomaterials on the basis of various layered systems have been intensively developed [1]. Intercalated layered systems are of great interest for the synthesis of sorbents and catalyst carriers, superionic conductors, optical and photoactive materials, nanomagnets, adsorbents, electrodes and membranes [2-3].

In particular, montmorillonite (MM) intercalated by polyhydroxocomplexes of various metals from solutions and sols enables obtaining pillared structures [4-6] by annealing: nanoparticles of oxides of various metals (pillars) are relatively uniformly distributed in the interlayer space and immobilized by crosslinking with silicate layers. Due to its increased basal distance $d_{001}$ and regular distribution of nanoparticles pillared montmorillonite has unique textural and physico-chemical properties such as developed surface area, large volume of micro- and mesopores, thermal stability, and the presence of active centers of various nature.

Intercalation of the $\left[\mathrm{Al}_{13} \mathrm{O}_{4}(\mathrm{OH})_{24}\left(\mathrm{H}_{2} \mathrm{O}\right)_{12}\right]^{7+}$ ions (abbreviated as $\mathrm{Al}_{13}$ ) $[2,4,5,7]$, which represent Keggin-type structures $\left[\mathrm{XM}_{12} \mathrm{O}_{40}\right]^{\mathrm{n}-}$, is most well studied. Introducing $\mathrm{Al}_{13}$ ions into the interlayer space leads to an increase in the basal distance $d_{001}$ of $\mathrm{Al}_{13}$-pillared MM by a few angstroms compared to source MM and a significant increase in specific surface area and porosity $[2,4,5]$. It has been recently shown by us [8-9] and Jianxi et al. [10-11] that these characteristics can be further increased by intercalating "giant" aluminum polycations $\left[\mathrm{Al}_{30} \mathrm{O}_{8}(\mathrm{OH})_{56}\left(\mathrm{H}_{2} \mathrm{O}\right)_{26}\right]^{18+}\left(\mathrm{Al}_{30}\right)$ (consisting of two $\mathrm{Al}_{13} \delta$ isomers and a bridge of four $\mathrm{AlO}_{6}$ octahedra) obtained by high-temperature hydrolysis of $\mathrm{Al}_{13}$.

It is obvious that textural characteristics of pillared materials can be improved by increasing the efficiency of intercalating polyhydroxocomplexes of metals. On the one hand, this can be achieved by using 
physical methods to activate intercalation, in particular, microwave radiation and ultrasonically [12-13]. Another approach proposed in the present work concerns preliminary mechanical activation of the layered substrate itself. The use of mechanoactivation in this case should be aimed at increasing, first, the specific surface area of clay particles and, second, their cation exchange capacity. In this case, a short-term mechanical treatment is necessary, which does not lead to a significant change in crystal structure of MM [14]. In our previous stud [15] it was shown that preliminary mechanical treatment of natural MM increased substantially the textural properties of $\mathrm{Al}_{13}$-pillared MM. A key role in increasing the capacity of the cation exchange of mechanically activated montmorillonite is played by the small dimensions of the tactoids (about $100 \mathrm{~nm}$ ) in an aqueous suspension. To a lesser extent, the efficiency of intercalation is influenced by the processes of defect formation and associated changes in the electrical properties of silicate montmorillonite layers.

The goal of this work is to study the effect of preliminary mechanical treatment of natural $\mathrm{MM}$ on the efficiency of intercalating $\mathrm{Al}_{30}$ ions and textural properties of the resulting pillared MM. For the sake of comparison with $\mathrm{Al}_{13}$-pillared $\mathrm{MM}$, all the conditions of mechanical treatment were kept the same as in [15].

\section{EXPERIMENTAL}

\section{Source materials}

The montmorillonite used in this work is the same as in [16] and has the following chemical composition, mass. \%: $\mathrm{SiO}_{2}-57.70 ; \mathrm{TiO}_{2}-1.04 ; \mathrm{Al}_{2} \mathrm{O}_{3}-13.75$; $\mathrm{Fe}_{2} \mathrm{O}_{3}$ - 5.36; $\mathrm{FeO}-0.20 ; \mathrm{CaO}-2.49 ; \mathrm{MgO}-3.13$; $\mathrm{Na}_{2} \mathrm{O}-1.74 ; \mathrm{K}_{2} \mathrm{O}-0.24 ; \mathrm{P}_{2} \mathrm{O}_{5}-0.16 ; \mathrm{SO}_{3}-0.65 ; \mathrm{BaO}$ -0.08 ; loss on ignition -13.46 . The main "impurity" minerals are cristobalite, quartz, plagioclase, calcite and gypsum. The composition of exchangeable cations (mg-eq/100 g): $\mathrm{Ca}^{2+}-24.69 ; \mathrm{Mg}^{2+}-22.74 ;\left(\mathrm{Na}^{+}+\mathrm{K}^{+}\right)$ -51.33 , total -98.76 .

\section{Mechanical treatment}

Mechanically activated MM (hereafter referred to as AMM) was produced in an AGO-2C planetary centrifugal mill (Russia) for 3 min using highstrength zirconium grinding media at a constant rotor speed of $1500 \mathrm{rpm}$; the weight ratio for MM and grinding media is 7.5:1.

Preparation of intercalated and pillared samples

The solution containing $\mathrm{Al}_{30}$ polycations was obtained by a hydrothermal technique, in which the solution containing $\mathrm{Al}_{13}$ was kept at $127^{\circ} \mathrm{C}$ for $5 \mathrm{~h}$. The solution containing $\mathrm{Al}_{13}$ polycations was prepared by hydrolysis of aluminum chloride: $0.2 \mathrm{M} \mathrm{NaOH}$ solution (Sigma Aldrich) was added to $0.2 \mathrm{M}$ solution of $\mathrm{AlCl}_{3} \cdot 6 \mathrm{H}_{2} \mathrm{O}$ (Fluka) until an $\left[\mathrm{OH}^{-}\right] /\left[\mathrm{Al}^{3+}\right]$ molar ratio of 2.4 was obtained at $\mathrm{pH} 4.3-4.7$ and room temperature. The solution was then aged for $24 \mathrm{~h}$ at $60^{\circ} \mathrm{C}$, resulting in the formation of $\mathrm{Al}_{13}$ polyhydroxocomplexes [5, 17-18]. Deionized water was used in all cases. The formation of the polycations was confirmed by the variety of methods as described in [9].

Intercalation of $\mathrm{MM}$ and $\mathrm{AMM}$ by $\mathrm{Al}_{30}$ polycations was carried out by means of ion exchange in a $1 \%$ aqueous suspension by introducing an intercalating solution $\left(3 \mathrm{mmol} \mathrm{Al}^{3+} / 1 \mathrm{~g} \mathrm{MM}\right)$ dropwise, while agitating intensively with a magnetic stirrer for $2 \mathrm{~h}$ at $80^{\circ} \mathrm{C}$. After $12 \mathrm{~h}$ of coagulation at room temperature, the suspension was washed to remove $\mathrm{Cl}^{-}$ions, centrifuged and dried in a drying oven at a temperature of $60^{\circ} \mathrm{C}$.

Pillared materials were obtained by annealing intercalated samples in an oven at $350{ }^{\circ} \mathrm{C}$ for $3 \mathrm{~h}$. The designations used for these, like for $\mathrm{Al}_{13}$ case [15], are as follows: $\mathrm{Al}_{30}-\mathrm{PMM}$, and $\mathrm{Al}_{30}-\mathrm{PAMM}$.

\section{Research methods}

Monitoring the efficiency of intercalating aluminum polyhydroxocomplexes into studied materials was performed by a UV-Vis U-2010 spectrophotometer («Hitachi», Japan): the photometric technique is based on the ability of aluminum ion to yield an orange-red colored complex compound upon treatment with aluminon (triammonium salt of aurintricarboxylic acid $\left.\left(\mathrm{NH}_{4} \mathrm{OOCC} \mathrm{H}_{3} \mathrm{OH}\right)_{2} \mathrm{C}=\mathrm{C}_{6} \mathrm{H}_{3}(\mathrm{O}) \mathrm{COONH}_{4}\right)$, which is then photographed at a wavelength of 525-540 nm). Measuring the basal distance $\mathrm{d}_{001}$ of the samples by Xray patterns was performed using a Bruker D8 Advance diffractometer (Bruker-AXS, Germany) with $\mathrm{CuK} \alpha$ radiation $(\lambda=0.154056 \mathrm{~nm})$ at $40 \mathrm{kV}$. Porosimetric measurements were carried out by low-temperature nitrogen adsorption-desorption using an ASAP 2020 specific surface area and porosity analyzer («Micromeritics», USA); prior to measurements, the samples were degassed at $180{ }^{\circ} \mathrm{C}$ and a residual pressure of 5-10 $\mathrm{Pa}$ for 3,5 $\mathrm{h}$.

\section{RESULTS AND DISCUSSION}

The intercalation efficiency was evaluated by the photometric method, which makes it possible to determine the concentration of aluminum ions in the intercalating solution before and after completion of the intercalation and, accordingly, the aluminum content in the sample. Table 1 reveals that mechanoactivation increases the gross capacity of the cation exchange of montmorillonite. 
Table 1

$\mathrm{Al}^{3+}$ ion concentration in the intercalating solution Таблица 1. Концентрация ионов $\mathrm{Al}^{3+}$ в интеркалирующем растворе

\begin{tabular}{|c|c|c|}
\hline \multirow{4}{*}{} & \multicolumn{2}{|c|}{$\mathrm{Al}^{3+}$ content } \\
\cline { 2 - 3 } & in the solution, $\mathrm{mg} / \mathrm{L}$ & in the sample, $\mathrm{mg} / \mathrm{g}$ \\
\cline { 2 - 3 } & \multicolumn{2}{|c|}{ Before intercalation } \\
\cline { 2 - 3 } & 5200 & \\
\cline { 2 - 3 } MM & \multicolumn{2}{|c|}{ After intercalation } \\
\hline AMM & 760 & 649 \\
\hline
\end{tabular}

Fig. 1 shows small-angle diffractograms of the investigated montmorillonite samples. A decrease in intensity and broadening of the reflex (001) after mechanical treatment of MM indicates some amorphization of the AMM structure and destabilization of the basal plane [14]. The increase in $d_{001}$ by about $0.3 \mathrm{~nm}$ in AMM $(1.56 \mathrm{~nm})$ compared to MM $(1.26 \mathrm{~nm})$ is due to the peeling of single layers after mechanoactivation [19]. Moreover, we believe that one should not rule out the diffusion of charge-compensating small-radius ions from the interlayer space into partially deformed and broken units of silicate layers, which should also result in an increase in $d_{001}$.

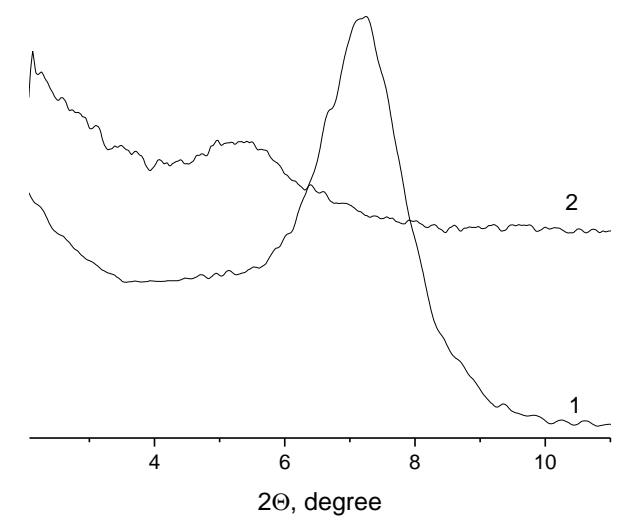

a

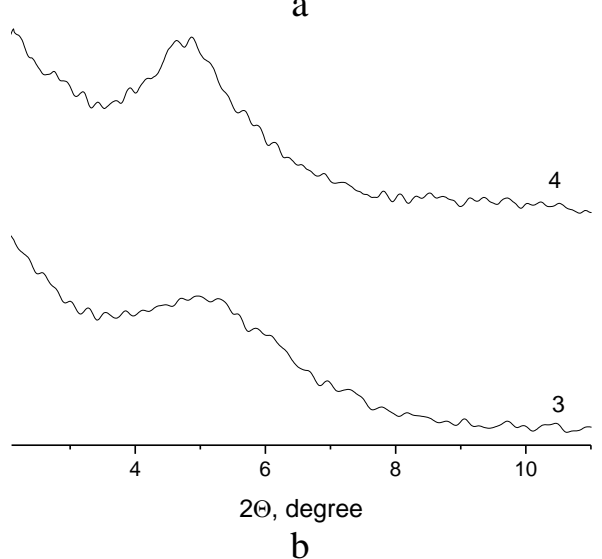

Fig. 1. Low-angle diffractograms: a) 1 - MM, $2-\mathrm{Al}_{30}-\mathrm{PMM}$; b) 3 - AMM, 4 - $\mathrm{Al}_{30}$-PAMM

Рис. 1. Малоугловые дифрактограммы: а) 1 - MM, 2 - $\mathrm{Al}_{30}$-PMМ; b) 3 - $\mathrm{AMM}, 4-\mathrm{Al}_{30}$-PAMM
In Table 2 the basal distances of the $\mathrm{Al}_{30}-\mathrm{PMM}$ and $\mathrm{Al}_{30}$-PAMM are given along with those for previously studied $\mathrm{Al}_{13}-\mathrm{PMM}$ and $\mathrm{Al}_{13}-\mathrm{PAMM}$ [15] for the comparison. One can see that for both types of Keggin ions intercalated the values of $d_{001}$ are larger in the case of mechanical treatment. The $\mathrm{Al}_{30}$-PAMM demonstrates the largest spacing of silicate layers, which is by $0.12 \mathrm{~nm}$ larger than that in $\mathrm{Al}_{13}-\mathrm{PAMM}$.

Fig. 2 shows the isotherms of low-temperature nitrogen adsorption-desorption for the obtained pillared materials. For all samples, nitrogen adsorption isotherms are of type IV according to the IUPAC classification and are characterized by a capillary-condensation hysteresis loop, which is typical for mesoporous materials. The shape of the hysteresis loop is of type $\mathrm{H} 3$, which is characteristic of porous materials with slit-shaped and plane-parallel pore [20]. Smaller hysteresis loop on the isotherms of $\mathrm{Al}_{30}$-PAMM compared to $\mathrm{Al}_{30}-\mathrm{PMM}$ indicates the greater number of mesopores between the silicate layers. $\mathrm{Al}_{30}-\mathrm{PAMM}$ shows higher adsorption capacity than $\mathrm{Al}_{30}$-PMM.

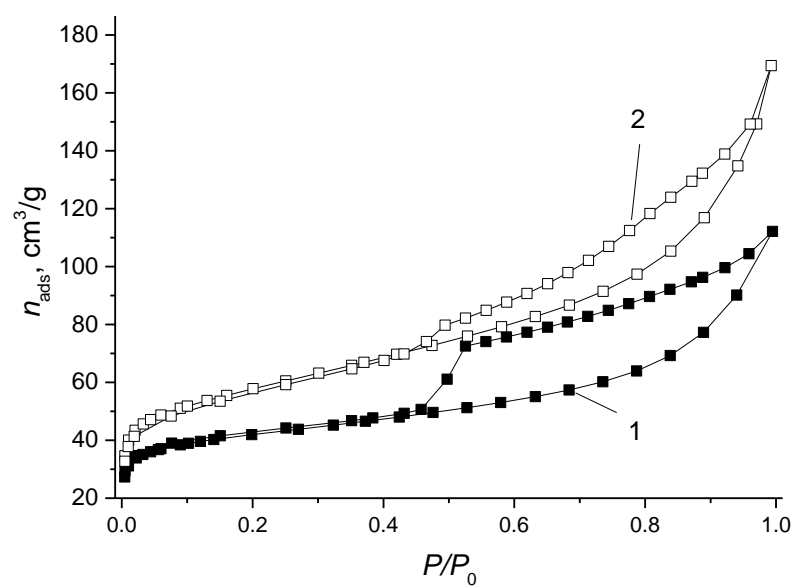

Fig. 2. Nitrogen adsorption/desorption isotherms: $1-\mathrm{Al}_{30}-\mathrm{PMM}$, $2-\mathrm{Al}_{30}$-PAMM

Рис. 2. Изотермы адсорбции/десорбции азота: 1 - $\mathrm{Al}_{30}-\mathrm{PMM}$, $2-\mathrm{Al}_{30}-\mathrm{PAMM}$

The specific surface area $\left(S_{\mathrm{BET}}\right)$ and total pore volume ( $\left.\Sigma V_{\text {por }}\right)$ in both $\mathrm{Al}_{13}-[15]$ and $\mathrm{Al}_{30}$-pillared samples are presented in Table 2. One can see that after mechanical treatment these characteristics increase substantially. From the data in Table 2 it follows that mechanical treatment in the $\mathrm{Al}_{13}-\mathrm{PAMM}$ case resulted in significant increase in both micro- $\left(V_{\mathrm{mp}}\right)$ and mesoporosity ( $\left.V_{\mathrm{msp}}\right)$. In the $\mathrm{Al}_{30}$-PAMM case the increase in mesoporosity due to mechanical treatment is even more pronounced whereas the volume of micropores somewhat decreases in comparison with untreated samples. 
Textural characteristics and basal distances Таблица 2. Текстурные характеристики и базальные расстояния

\begin{tabular}{|c|c|c|c|c|c|c|}
\hline Sample & $\begin{array}{c}d_{001}, \\
\mathrm{~nm}\end{array}$ & $\begin{array}{c}S_{\mathrm{BET}}, \\
\mathrm{m}^{2} / \mathrm{g}\end{array}$ & $\begin{array}{c}V_{\mathrm{mp}}, \\
\mathrm{cm}^{3} / \mathrm{g}\end{array}$ & $\begin{array}{c}V_{\mathrm{msp}}, \\
\mathrm{cm}^{3} / \mathrm{g}\end{array}$ & $\begin{array}{c}\sum V_{\text {por }}, \\
\mathrm{cm}^{3} / \mathrm{g}\end{array}$ & $\begin{array}{c}D_{\text {av }} \\
\mathrm{nm}\end{array}$ \\
\hline $\mathrm{Al}_{13}-\mathrm{PMM} \mathrm{[15]}$ & 1.63 & 108 & 0.029 & 0.137 & 0.166 & 8.42 \\
\hline $\begin{array}{c}\mathrm{Al}_{13}-\mathrm{PAMM} \\
{[15]}\end{array}$ & 1.76 & 169 & 0.040 & 0.210 & 0.250 & 5.84 \\
\hline $\mathrm{Al}_{30}-\mathrm{PMM}$ & 1.69 & 125 & 0.035 & 0.138 & 0.173 & 8.04 \\
\hline $\mathrm{Al}_{30}-\mathrm{PAMM}$ & 1.88 & 182 & 0.031 & 0.231 & 0.262 & 7.11 \\
\hline
\end{tabular}

The pore size distribution curves for all the samples are shown in Fig. 3. Preliminary mechanical treatment of montmorillonite does not fundamentally change the unimodal pore size distribution, however, in this case the curve maximum shifts towards smaller pore sizes. This observation is in accordance with the notion that an increase in the number of intercalated polycations should lead to a decrease in the pore size.

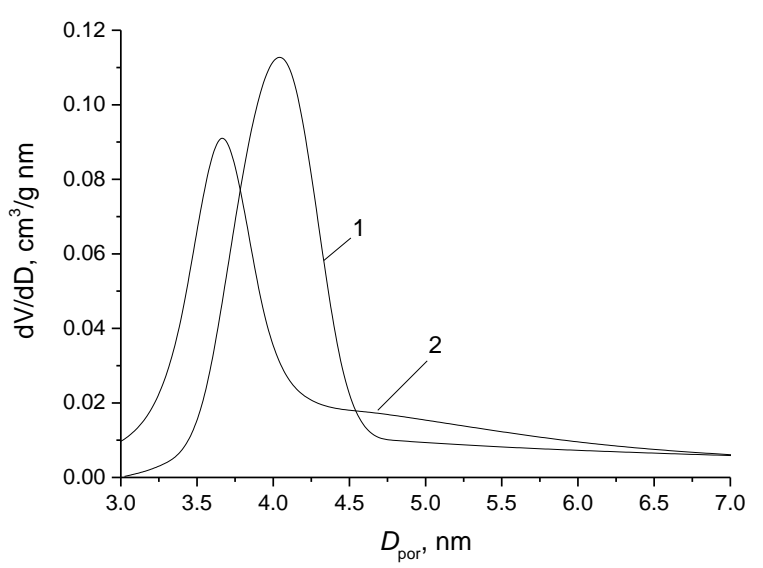

Fig. 3. Pore size distribution curves: $1-\mathrm{Al}_{30}-\mathrm{PMM}, 2-\mathrm{Al}_{30}-\mathrm{PAMM}$ Рис. 3. Кривые распределения пор по размерам: 1 - $\mathrm{Al}_{30}-\mathrm{PMM}$, $2-\mathrm{Al}_{30}-\mathrm{PAMM}$

\section{CONCLUSION}

The possibility of increasing the efficiency of intercalating the $\mathrm{Al}_{30}$ ions in the preparation of pillared structures by means of preliminary mechanical treatment of natural montmorillonite has been studied. In the case of mechanical treatment, an increase in the content of the $\mathrm{Al}^{3+}$ ions by $13 \%$ in the montmorillonite matrix after intercalating $\mathrm{Al}_{30}$ was observed. It has been established that preliminary mechanical treatment of montmorillonite allows one to significantly (approximately by $50 \%$ ) enhance textural characteristics, in particular, to increase the specific surface area and total porosity of pillared materials; this increases mostly mesoporosity, and pore sizes decrease by approximately $12 \%$. This result demonstrates the particular importance of the size of intercalated montmorillonite particles for the resulting porosity of the pillared material. A decrease in the size of the MM particles during mechanical treatment enables, first of all, increasing the area of the interphase boundary through which ion exchange takes place. Apparently, this factor becomes decisive in the process of intercalation and further formation of the pillared structure.

\section{ACKNOWLEDGEMENTS}

This work was supported by the RFBR foundation (16-03-01016-a). A.V.V. thanks the Ministry of Education and Science of the Russian Federation (Project 11.1706.2017/4.6) for financial support.

\section{REFERENCES \\ ЛИТЕР А Т У Р А}

1. Fernandes F.M., Baradari H., Sanchez C. Integrative strategies to hybrid lamellar compounds: an integration challenge. Appl. Clay Sci. 2014. V. 100. P. 2-21. DOI: 10.1016/j.clay.2014.05.013.

2. Bergaya F., Theng B. K. G., Lagaly G. Handbook of Clay Science. 1st Edition (Developments in Clay Science). Amsterdam: Elsevier Ltd. 2006. V. 1. P. 393.

3. Ye W., Zhao B., Gao H., Huang J., Zhang X. Preparation of highly efficient and stable $\mathrm{Fe}, \mathrm{Zn}$, Al-pillared montmorillonite as heterogeneous catalyst for catalytic wet peroxide oxidation of Orange II. J. Porous Mater. 2016. V. 23. P. 301-310. DOI: 10.1007/s10934-015-0082-y.

4. Bergaya F., Lagaly G. Handbook of Clay Science. 2nd Edition (Developments in Clay Science). Amsterdam: Elsevier Ltd. 2013. V. 5. P. 524.

5. Gil A., Korili S.A., Vicente M.A. Recent advances in the control and characterization of the porous structure of pillared clay catalysts. Cat. Rev.-Sci. Eng. 2008. V. 50. P. 153-221. DOI: $10.1080 / 01614940802019383$.

6. Wang Y., Zhang P., Wen K., Su X., Zhu J., He H. A new insight into the compositional and structural control of porous clay heterostructures from the perspective of NMR and TEM. Micropor. Mesopor. Mater. 2016. V. 224. P. 285-293. DOI: 10.1016/j.micromeso.2015.12.053.

7. Chávez-García M. L., de Pablo-Galán L., Saucedo-Ramírez M.P. Synthesis of intercalated Al-hydroxy-montmorillonite. J. Mex. Chem. Soc. 2006. V. 50. N 1. P. 36-41.

8. Butman M. F., Ovchinnikov N. L., Arbuznikov V. V., Agafonov A. V., Nuralyev B. Synthesis of $\mathrm{Al}_{2} \mathrm{O}_{3}$-pillared montmorillonite by intercalation of «giant» aluminum polycations. Pisma Mater. 2013. V. 3. P. 284-287 (in Russian). Бутман М.Ф., Овчинников Н.Л., Арбузников В.В., Агафонов А.В., Нуралыев Б. Синтез $\mathrm{Al}_{2} \mathrm{O}_{3}$-пилларированного монтмориллонита интеркаляцией "гигантских" поликатионов алюминия. Письма о материалах. 2013. Т. 3. № 4. С. 284-287.

9. Butman M.F., Belozerov A.G., Karasev N.S., Kochkina N.E., Khodov I.A., Ovchinnikov N.L. Structural and textural properties of pillared montmorillonite at intercalation of large Al- and Al/Ce-polyhydroxocomplexes. Nanotechnol. in Russia. 2015. V. 10. N 9-10. P. 706-712 (in Russian). DOI: 10.1134/S1995078015050031.

Бутман М.Ф., Белозеров А.Г., Карасев Н.С., Кочкина Н.Е., Ходов И.А., Овчинников Н.Л. Структурные и текстурные свойства пилларного монтмориллонита при ин-

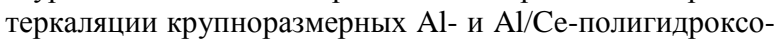
комплексов. Росс. нанотехнол. 2015. Т. 10. № 9. C. $29-34$. 
10. Zhu J., Wen K., Zhang P, Wang Y., Ma L, Xi Y., Zhu R., Liu H., He H. Keggin-Al 30 pillared montmorillonite. $M i$ cropor. Mesopor. Mater. 2017. V. 242. P. 256-263. DOI 10.1016/j.micromeso.2017.01.039.

11. Zhu J., Wen K., Wang Y., Ma L., Su X., Zhu R., Xid Y., He H. Superior thermal stability of Keggin-Al 30 pillared montmorillonite: A comparative study with Keggin- $\mathrm{Al}_{13}$ pillared montmorillonite. Micropor. Mesopor. Mater. 2018. V. 265. P. 104-111. DOI: 10.1016/j.micromeso.2018.02.007.

12. Yapar S., Torres Sanchez R. M., Emreol M., Weidler P., Emmerich K. Microwave irradiation used for all steps of prepillaring Al-mintmorillonite. Clay Minerals. 2009. V. 44. N 2. P. 267-278. DOI: 10.1180/claymin.2009.044.2.267.

13. Katdare S.P., Ramaswamy V., Ramaswamy A.V. Preparation of alumina pillared montmorillonite clays employing ultrasonics and their catalytic properties. Micropor. Mesopor. Mater. 2000. V. 2. N 1. P. 53-58. DOI: 10.18321/ectj357.

14. Al-Qunaibit M.M., Al Juhaiman L. Mechanical modification of Khulays clay; structural and textural effects. Int. J. Basic Applied Sciences. 2012. V. 12. N 6. P. 205-209.

15. Ovchinnikov N.L., Arbuznikov V.V., Kapinos A.P., Belozerov A.G., Butman M.F. Effect of mechanical activation of montmorillonite on the intercalation efficiency of polyhydroxyaluminum cations in the formation of pillar structure. Nanotechnol. in Russia. 2015. V. 10. N 3-4. P. 254-260 (in Russian). DOI: 10.1134/S1995078015020159.
Овчинников Н.Л., Арбузников А.В., Капинос А.П., Белозеров А.Г., Бутман М.Ф. Влияние механоактивации монтмориллонита на эффективность интеркаляции полигидроксокомплексов алюминия при формировании слоисто-столбчатой структуры. Росс. нанотехнол. 2015. Т. 10. №. 3. С. 64 -69.

16. Nasedkin V.V. Dash-Salakhli bentonite deposit (formation and prospects of development). M: GEOS. 2008. 85 p. (in Russia). Наседкин В.В. Даш-Салахлинское месторождение бентонита (становление и перспективы развития). М.: ГЕОС. 2008. С. 85.

17. Guerra L.D., Airoldi C., Lemos V.P., Angelica R.S. Adsorptive, thermodynamic and kinetic performance of $\mathrm{Al} / \mathrm{Ti}$ and $\mathrm{Al} / \mathrm{Zr}$-pillared clays from the Brazilian Amazon region for zinc cation removal. J. Hazard. Mater. 2008. V. 155. N 1-2. P. 230-242. DOI: 10.1016/j.jhazmat.2007.11.054.

18. Zuo S., Zhou R. Influence of synthesis condition on pore structure of Al pillared clays and supported Pd catalysts for deep oxidation of benzene. Micropor. Mesopor. Mater. 2008. V. 113. P. 472-480. DOI: 10.1016/j.micromeso.2007.12.005.

19. Xia M., Jiang Y., Zhao L., Li F., Xue B., Sun M., Liu D., Zhang X. Wet grinding of montmorillonite and its effect on the properties of mesoporous montmorillonite. Colloids Surf. 2010. V. 356. P. 1-9. DOI: 10.1016/j.colsurfa.2009.12.014.

20. Sing K.S.W., Everett D.H., Haul R.A.W. Reporting physisorption data for gas/solid systems with special reference to the determination of surface area and porosity. Pure Appl. Chem. 1984. V. 57. N 4. P. 603-619. DOI: 10.1351/pac198557040603.

Поступила в редакцию 10.12.2018

Принята к опубликованию 14.11.2019

Received 10.12.2018

Accepted 14.11.2019 